\title{
Physicochemical Properties and Selected Heavy Metals in Tin- Mine Spoil Soils around Jos Plateau Nigeria
}

\author{
Ideriah T.J. K. ${ }^{1}$, Abere S.A. ${ }^{2}$ \\ ${ }^{1}$ Institute of Pollution Studies. \\ ${ }^{2}$ Department of Forestry and Environment, Rivers State University Port Harcourt, Nigeria
}

\begin{abstract}
The physicochemical properties and heavy metals in both vegetated and non-vegetated spoil soils in Jos Plateau were determined. Three dug soil profiles and thirty three composite soil samples were collected with auger at depths of 0 $15 \mathrm{~cm}, 15-30 \mathrm{~cm}$ and $30-50 \mathrm{~cm}$ and analysed using standard methods. The results showed mean value ranges of $4.58-5.28$ pH, $0.09-1.46$ Organic matter, 42 84\% Sand, $6-46 \%$ clay, 5 -29\% silt, $0.022-0.110 \%$ total nitrogen, $14.80-41.44 p p m$ available phosphorus, $3.13-5.00 \mathrm{meq} / 100 \mathrm{~g}$ exchangeable calcium, $1.45-2.35 \mathrm{meq} / 100 \mathrm{~g}$ exchangeable magnesium, $0.04-$ $0.51 \mathrm{meq} / 100 \mathrm{~g}$ exchangeable potassium, $0.15-0.20 \mathrm{meq} / 100 \mathrm{~g}$ exchangeable sodium, $8.16-12.28 \mathrm{meq} / 100 \mathrm{~g}$ CEC126.80 778.33ppm Fe, $0.16-0.44 \mathrm{ppm} \mathrm{Al}$ and 5.50-23.50ppm Mn. The soils were found to be predominantly Sandy Clay Loam, acidic and deficient in nutrients, Nitrogen, Phosphorus and Exchangeable Bases. The concentrations of most parameters were higher in the cultivated spoil soils than in the uncultivated spoil soils. Land amendment materials such as organic wastes and town refuse ash should be applied to the soils in the area.
\end{abstract}

Keywords-Tin mine, Spoil soils, Vegetated, Non-Vegetated, Jos Plateau, Nutrients, Cultivated.

\section{INTRODUCTION}

Nigeria's tin mining industry is situated on the Jos Plateau more than $1300 \mathrm{~m}$ above sea level.

Mining activities have been identified as a major cause of land degradation the world over (World Bank, 1995). The physical and chemical characteristics of mine soils affect reclamation efforts. These characteristics vary depending on the quality of the original soil, the amount and size of pulverized bedrock included in the spoil and the method of placement (Reuter, 2001). Generally, however, the properties of mine soils make them a poor medium for plant growth (Sengupta, 1993). This is because removal and crushing of bedrock exposes geologic material that is not stable at earth surface conditions and the alteration of this material impacts the chemistry of the environment (Reuter, 2001).

Mining activities have been identified as a major cause of land degradation the world over (World Bank, 1995). The physical and chemical characteristics of mine soils affect reclamation efforts. These characteristics vary depending on the quality of the original soil, the amount and size of pulverized bedrock included in the spoil, and the method of placement (Reuter, 2001). Generally, however, the properties of mine soils make them a poor medium for plant growth and natural recolonization on these soils is slow (Sengupta, 1993).

About $320 \mathrm{~km}^{2}$ land area of the Jos Plateau has been degraded as a result of open cast tin mining since 1904. Only about $30 \mathrm{~km}^{2}$ has been reclaimed thus leaving nearly $90 \%$ of the affected area derelict to some degree and only little reclamation has taken place since 1982 (Alexander, 1992).

The reclamation strategy adopted by the MLRU was a straightforward strategy involving the leveling of the spoil mounds and the infilling of the flooded excavations with the intention of returning the land to immediate agricultural production (Wimbush, 1963). Reclamation was rendered more difficult because at the beginning of mining, no attempt was made to adopt the normal strip-mine policy of removing and storing separately top soil, sub-soil and overburden. Consequently, the spoil mounds comprise a complex mixture of these various strata, which produces extremely acid and nutrient deficient soil parent material (Alexander, 1992).

Open cast tin mining in the area, among other factors, has led to shortage of arable lands. Subsequently, encroachment into marginal lands and the use of unproductive soils for farming is commonplace. Alexander (1989) reported that population pressure and land shortage reduced the period of fallow or even caused complete abandonment.

This study will examine soil constraints to natural vegetation growth on the tin mine spoils of the Rayfield area and Barkin Ladi LGA, both within the Jos Plateau. The soil categories include: unreclaimed / non-vegetated spoils, unreclaimed / 
vegetated spoils, reclaimed / vegetated spoils, cultivated spoils and about seven decades undisturbed soils. This study is aimed to assess the physicochemical properties of non-vegetated tin mine spoil soils on Jos Plateau.

\section{MATERIALS AND MethodS}

\subsection{Study Area}

Jos Plateau lies about $10^{\circ}$ North of the equator in the 'middle belt' of Nigeria and is a highland area of approximately $8,600 \mathrm{~km}^{2}$ occupying the northern part of Plateau State (Alexander and Kidd, 2000). It is bounded by latitudes $10^{\circ} 11^{\prime} \mathrm{N}$ and $8^{\circ} 55^{\prime} \mathrm{N}$ and longitudes $8^{\circ} 21^{\prime} \mathrm{E}$ and $90^{\circ} 30^{\prime} \mathrm{E}$ with an average elevation of about $1,250 \mathrm{~m}$ above mean sea level (Ajaegbu, 1992) (Fig. 1a).

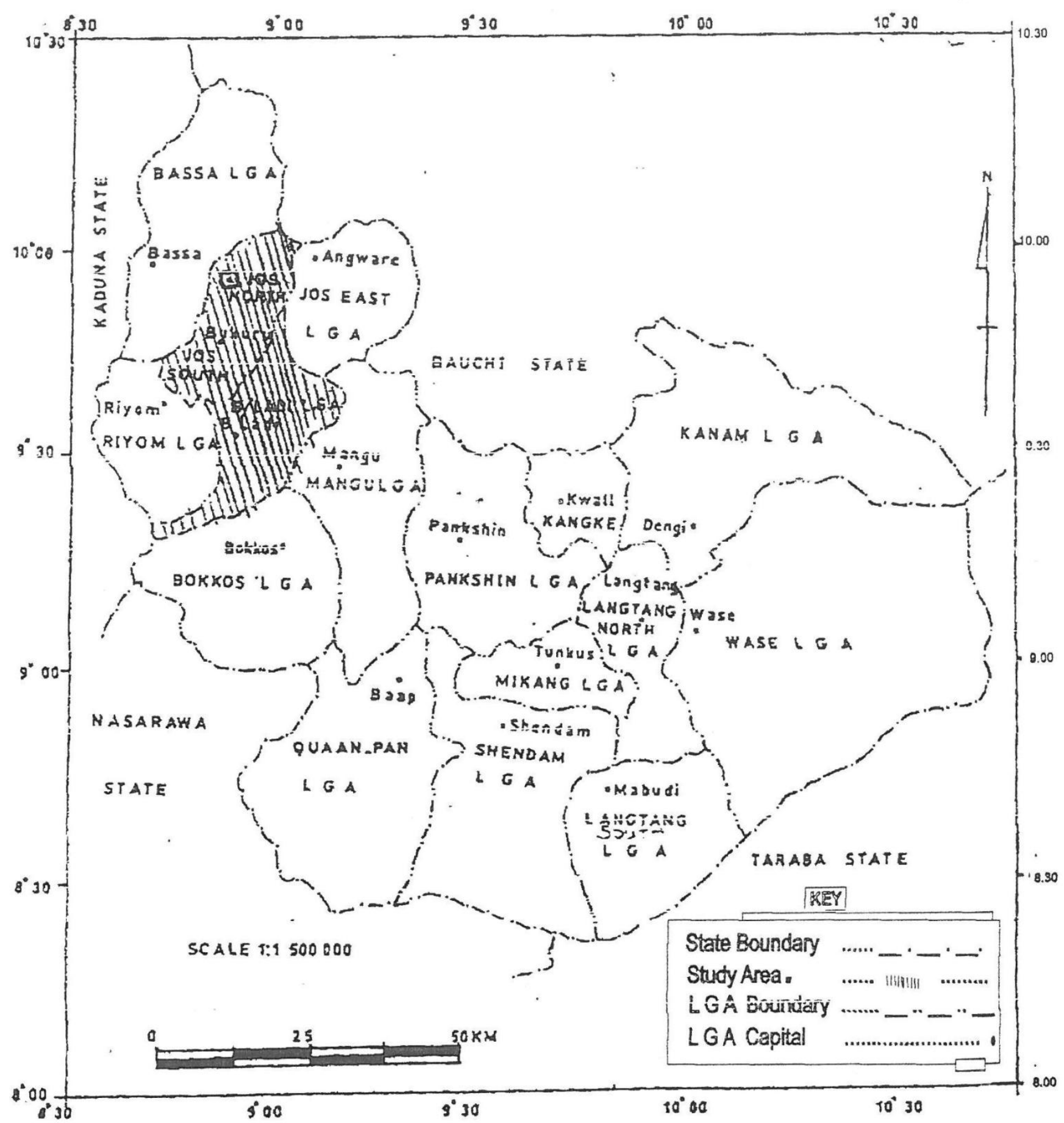

Figure 1A: MaP of Plateau State Showing the Study ARea 
The Jos Plateau is located within the Northern Nigerian Cystalline Complex (Macleod et al, 1971). In relation to the rest of the Northern Nigerian Crystalline Complex, it is its elevation above sea level $(1,250 \mathrm{~m})$ that makes it stand out (Ajaegbu, 1992). The area has a mean monthly temperature range of $20-24^{\circ} \mathrm{C}$ (table 3.1 ) and annual total rainfall of $1400 \mathrm{~mm}$ which falls primarily over a period from April to October (Alexander and Kidd, 2000).

Three distinct soil associations have been identified on the Jos Plateau by Alexander (1986). These are; soils associated with rock outcrops or lateritic pans, soils on newer basalts and soils on granite.

The Jos Plateau falls within the Northern Guinea Savannah zone which is open woodland with tall trees but the native vegetation has been considerably altered by human activities. Even where the natural vegetation is not disturbed by agriculture or mining, soil erosion is a hazard (Alexander, 1986).

\subsection{Description of Sampling Locations}

Soil samples were collected from:

$>$ Category 1:- Unreclaimed / vegetated spoils: vegetated mine dumps

> Category 2:- Unreclaimed / Non-vegetated spoils: mine dumps completely devoid of vegetation

> Category 3:- Reclaimed / vegetated spoil soils: mine dumps that were leveled and planted with Eucalyptus trees during reclamation. Eucalyptus is exotic species from Australia.

Category 4:- Cultivated spoil soils: mine spoil soils under cultivation

$>$ Category 5:- Undisturbed soils: unmined and uncultivated soils with grasses and few trees

Forty five soil samples were collected from dug profile pits by auger borings. For each auger boring, sample collection was at three pre-determined depths $(0-15 \mathrm{~cm}, 15-30 \mathrm{~cm}$ and $30-50 \mathrm{~cm})$. For each of these depths, samples were collected from four spots to obtain composite samples. After collection, the soil samples were stored in well labeled polythene bags before being sent to the laboratory for further preparation and analysis. Figure 1 shows map of the study area showing sample collection spots.

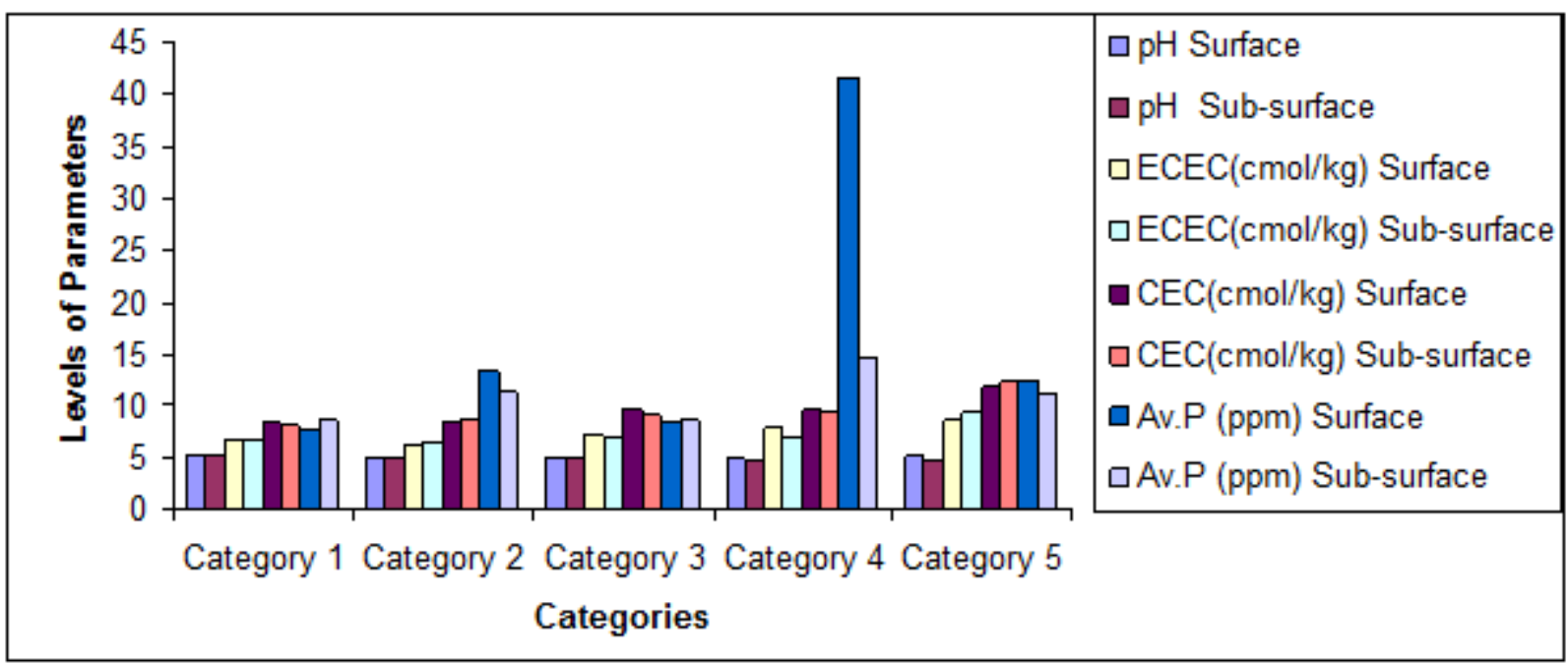

Figure 1: Variations in Levels of Physicochemical Parameters in Soils at the Study Area

\subsection{Analytical Methods}

The soil samples were air-dried for five days and screened through a $2 \mathrm{~mm}$ sieve. Particle size was determined by the hydrometer method (Day, 1965), modified by Gee and Bauder (1986). Soil reaction was determined in 1:2.5 soil/water ratio by the use of glass electrode $\mathrm{pH}$ meter. Organic matter was determined following the Walkey and Black (1934) method. Total Nitrogen was determined following the wet oxidation procedure modified by Bremner (1965). Available phosphorus was extracted using dilute $\mathrm{HCl} / \mathrm{NH}_{4} \mathrm{~F}$ (Bray-1) described by Bray and Kurtz (1945). The extraction of Ca, $\mathrm{Mg}$ and $\mathrm{K}$ was made using in ammonium acetate at pH 7.0 (USDA, 1972). Ca and Mg were measured by using an atomic absorption spectrophotometer (AAS) while $\mathrm{K}$ and $\mathrm{Na}$ were measured with the aid of flame photometer. Effective Cation Exchange Capacity was determined by summation method following the extraction of exchangeable acidity in IN KCl. Pyrophosphate 
extractable $\mathrm{Fe}, \mathrm{Al}$ and $\mathrm{Mn}$ were determined by atomic absorption spectrophotometry (AAS). Base saturation percentage (BSP) was calculated using the formula

$$
B S P=\frac{\left(\mathrm{Ca}^{++}+\mathrm{Mg} \mathrm{g}^{++}+\mathrm{K}^{+}+\mathrm{Na} \mathrm{a}^{+}\right)}{\text {Cation Exchange Capacity }} \times 100
$$

\section{RESULTS AND DISCUSSION}

\subsection{Physicochemical Properties of the Tin Mine Spoil}

The results of the physico-chemical parameters measured from the tin mine spoil soils are presented in Table 1 and Figs 1 3.

TABLE 1

MEAN LEVELS OF PHYSICO-CHEMICAL PROPERTIES MEASURED IN THE STUDY AREA

\begin{tabular}{|c|c|c|c|c|c|c|}
\hline \multirow[b]{2}{*}{ Parametres } & \multirow[b]{2}{*}{ Sampled } & \multicolumn{5}{|c|}{ Mean Levels } \\
\hline & & $\begin{array}{c}\text { Category } \\
1\end{array}$ & $\begin{array}{c}\text { Category } \\
2\end{array}$ & $\begin{array}{c}\text { Category } \\
\mathbf{3}\end{array}$ & $\begin{array}{c}\text { Category } \\
4\end{array}$ & $\begin{array}{c}\text { Category } \\
5\end{array}$ \\
\hline \multirow{2}{*}{$\mathrm{pH}$} & Surface & 5.08 & 4.95 & 4.82 & 4.99 & 5.28 \\
\hline & Sub-surface & 5.06 & 4.93 & 4.82 & 4.79 & 4.58 \\
\hline \multirow{2}{*}{$\mathrm{OM}(\%)$} & Surface & 0.09 & 0.36 & 0.32 & 1.41 & 0.28 \\
\hline & Sub-surface & 0.23 & 0.51 & 0.38 & 0.56 & 1.46 \\
\hline \multirow{2}{*}{ CLAY $(\%)$} & Surface & 28.75 & 22.00 & 18.00 & 19.00 & 12.00 \\
\hline & Sub-surface & 28.50 & 24.71 & 23.50 & 21.13 & 24.75 \\
\hline \multirow{2}{*}{$\operatorname{SAND}(\%)$} & Surface & 59.25 & 63.00 & 65.00 & 66.00 & 64.00 \\
\hline & Sub-surface & 59.00 & 61.71 & 60.50 & 66.00 & 56.50 \\
\hline \multirow{2}{*}{$\operatorname{SILT}(\%)$} & Surface & 12.00 & 15.00 & 17.00 & 15.00 & 24.00 \\
\hline & Sub-surface & 12.50 & 13.57 & 16.00 & 13.00 & 18.75 \\
\hline \multirow{2}{*}{$\begin{array}{c}\text { TOTAL N } \\
(\%)\end{array}$} & Surface & 0.022 & 0.041 & 0.044 & 0.076 & 0.105 \\
\hline & Sub-surface & 0.027 & 0.040 & 0.035 & 0.059 & 0.110 \\
\hline \multirow{2}{*}{ AV.P (PPM) } & Surface & 7.57 & 13.37 & 8.26 & 41.44 & 12.20 \\
\hline & Sub-surface & 8.65 & 11.30 & 8.65 & 14.80 & 11.02 \\
\hline \multirow{2}{*}{ Exch.Ca $(\mathrm{cmol} / \mathrm{kg})$} & Surface & 3.20 & 3.13 & 3.30 & 4.13 & 5.00 \\
\hline & Sub-surface & 3.33 & 3.40 & 3.15 & 3.40 & 3.75 \\
\hline \multirow{2}{*}{$\begin{array}{l}\text { Exch.Mg } \\
(\mathrm{cmol} / \mathrm{kg})\end{array}$} & Surface & 1.70 & 1.50 & 1.45 & 1.97 & 2.35 \\
\hline & Sub-surface & 1.58 & 1.79 & 1.53 & 1.79 & 2.23 \\
\hline \multirow{2}{*}{$\begin{array}{c}\text { Exch.K } \\
(\mathrm{cmol} / \mathrm{kg})\end{array}$} & Surface & 0.07 & 0.11 & 0.07 & 0.51 & 0.34 \\
\hline & Sub-surface & 0.09 & 0.04 & 0.05 & 0.10 & 0.20 \\
\hline Exch.Na(cm & Surface & 0.15 & 0.17 & 0.20 & 0.16 & 0.16 \\
\hline $\mathrm{ol} / \mathrm{kg}$ ) & Sub-surface & 0.15 & 0.17 & 0.19 & 0.18 & 0.17 \\
\hline \multirow{2}{*}{$\begin{array}{c}\text { Exch.Al+H } \\
(\mathrm{cmol} / \mathrm{kg})\end{array}$} & Surface & 1.40 & 1.27 & 2.20 & 2.07 & 0.80 \\
\hline & Sub-surface & 1.50 & 0.94 & 2.05 & 1.43 & 2.35 \\
\hline \multirow{2}{*}{ ECEC $(\mathrm{cmol} / \mathrm{kg})$} & Surface & 6.52 & 6.18 & 7.22 & 7.83 & 8.64 \\
\hline & Sub-surface & 6.64 & 6.49 & 6.97 & 6.89 & 9.45 \\
\hline \multirow{2}{*}{$\mathrm{CEC}(\mathrm{cmol} / \mathrm{kg})$} & Surface & 8.38 & 8.30 & 9.65 & 9.47 & 11.85 \\
\hline & Sub-surface & 8.16 & 8.71 & 9.10 & 9.39 & 12.28 \\
\hline \multirow{2}{*}{ BSP } & Surface & 61.29 & 58.79 & 51.86 & 73.18 & 65.70 \\
\hline & Sub-surface & 59.21 & 61.92 & 53.69 & 58.06 & 52.10 \\
\hline \multirow{2}{*}{$\mathrm{Fe}(\mathrm{ppm})$} & Surface & 137.50 & 281.70 & 256.25 & 778.33 & 342.50 \\
\hline & Sub-surface & 201.69 & 126.80 & 162.50 & 629.06 & 705.00 \\
\hline \multirow{2}{*}{$\mathrm{Al}(\mathrm{ppm})$} & Surface & 0.20 & 0.43 & 0.29 & 0.44 & 0.37 \\
\hline & Sub-surface & 0.24 & 0.21 & 0.16 & 0.36 & 0.42 \\
\hline \multirow{2}{*}{$\mathrm{Mn}(\mathrm{ppm})$} & Surface & 6.76 & 9.98 & 11.26 & 23.50 & 7.43 \\
\hline & Sub-surface & 5.50 & 13.08 & 7.49 & 10.34 & 9.58 \\
\hline
\end{tabular}




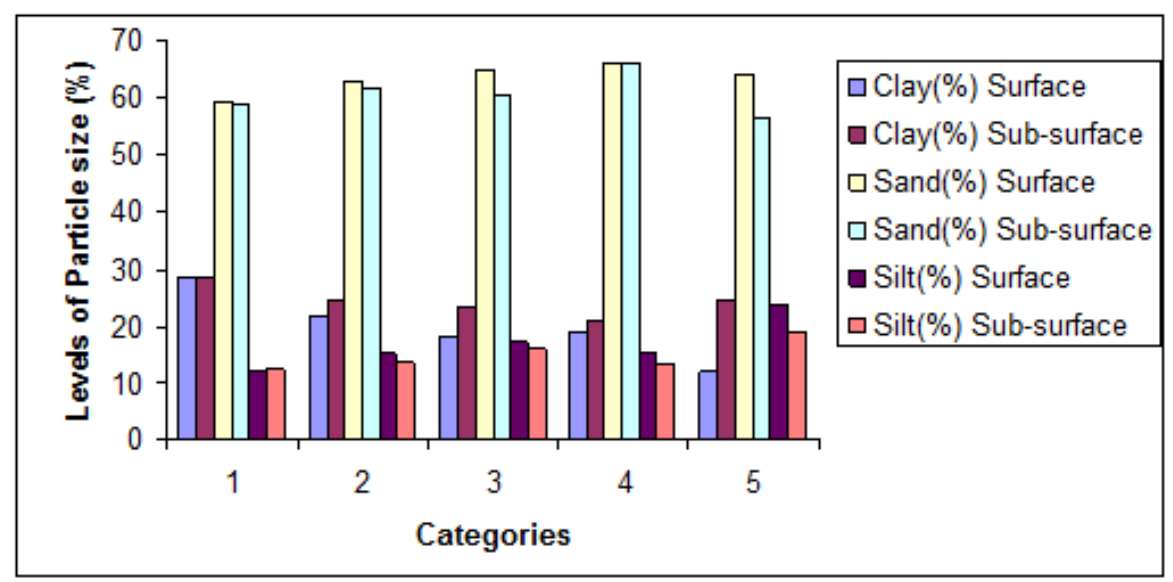

Figure 2: Variations in LeVels of Soils Particle Size at the StUdy Area

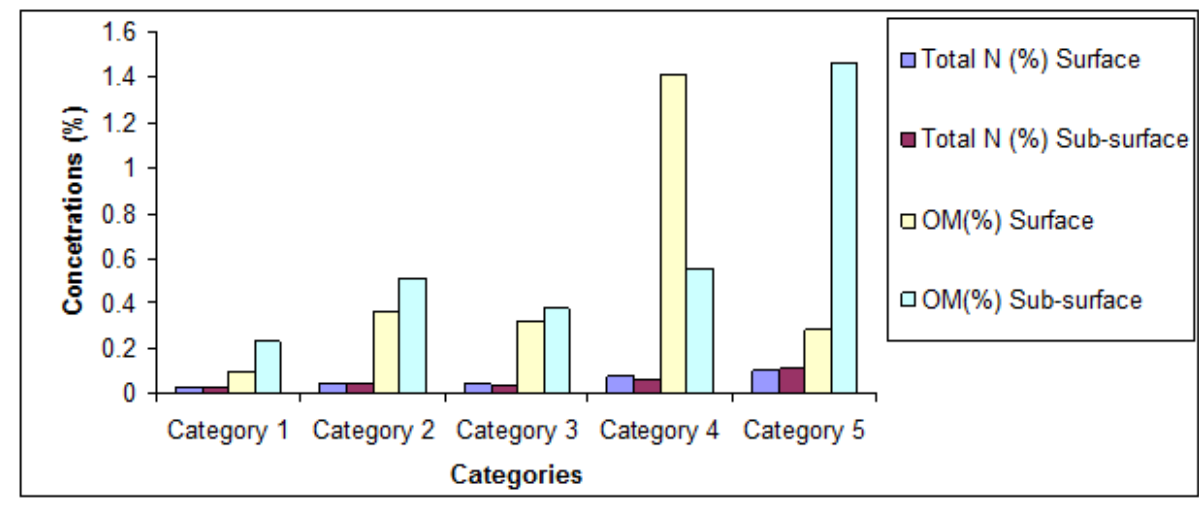

Figure 3: Variations in Concentrations of Chemical Parameters in SOIls at The Study Area

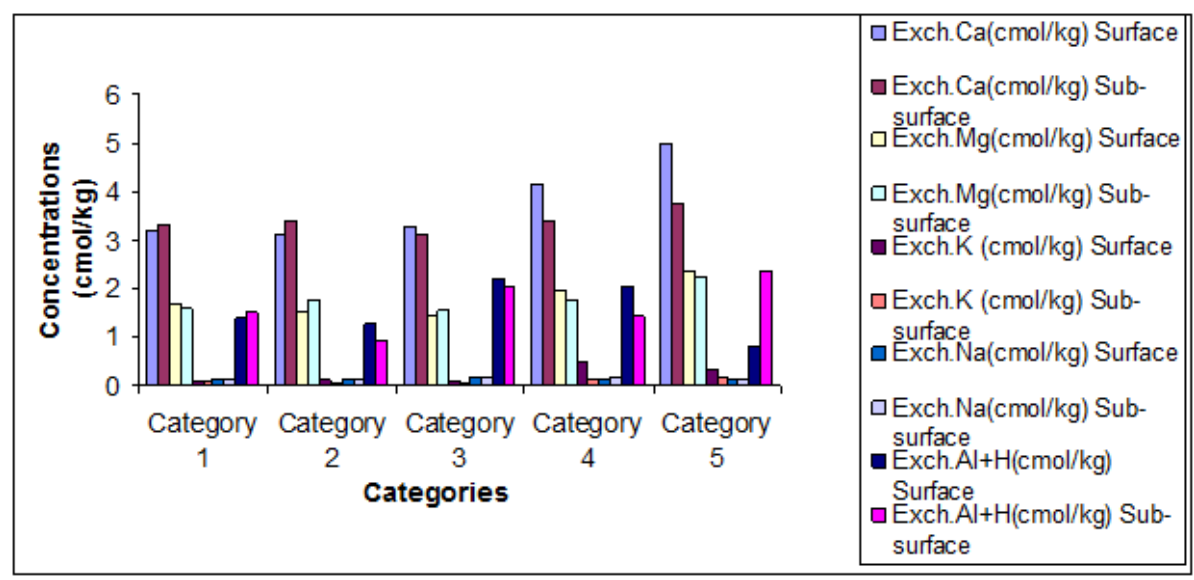

Figure 4: VARIATIONS IN CONCENTRATIONS OF EXChANGE CATIONS IN SOILS AT THE STUDY AREA

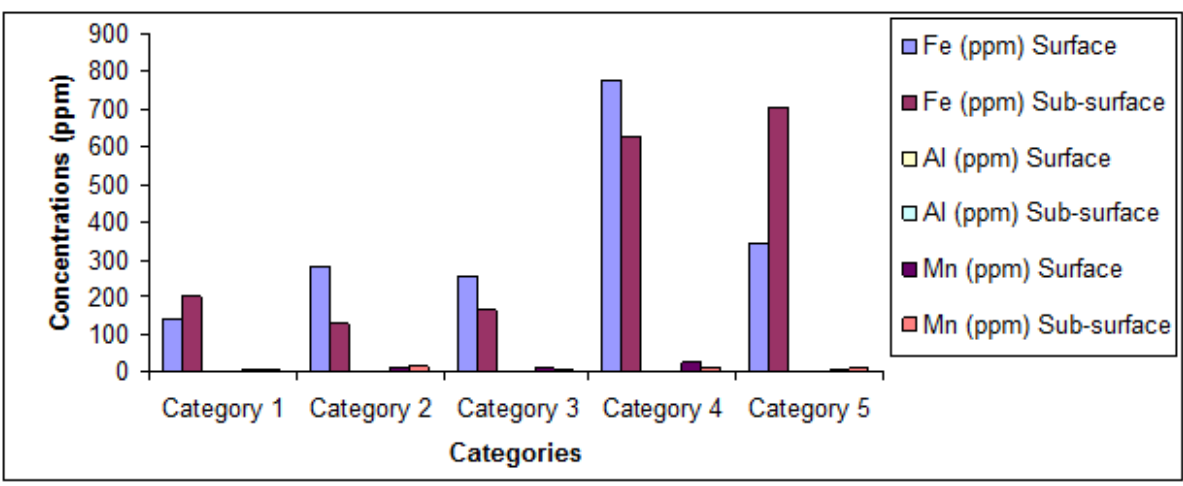

FigURE 4: VARIATIONS IN CONCENTRATIONS OF HEAVY METALS IN SOILS AT THE STUDY AREA 


\subsection{Soil pH}

Table 1 shows that irrespective of soil category or depth, all the samples analyzed were acidic. Mean $\mathrm{pH}$ values range from $4.58-5.28$. The soils were strongly acidic to very strongly acidic in reaction based on $\mathrm{pH}$ ratings by Truog (1948) and Brady and Weil (1994). The acidic nature of the granitic parent rock that underlies the Jos Plateau tin mining area (Olowolafe, 2002) as well as the abundance of laterites in the area may be responsible for the acidity of the soils. Low pH implies increased solubility and availability of toxic metals $(\mathrm{Fe}, \mathrm{Al}, \mathrm{Mn}$ ) and this could lead to reduced vegetation growth, reduced population of $\mathrm{N}$-fixing bacteria and allows for leaching of essential nutrients.

Remediation processes that can be employed towards proper management of the acidity of the soils of the study area include the use of organic amendment (plant and animal remains) and liming - which eliminates $\mathrm{Al}$ and $\mathrm{H}$ ions thereby raising soil $\mathrm{pH}$ and could also supply $\mathrm{Ca}$ and $\mathrm{Mg}$ if dolomite $\left[\mathrm{Ca}, \mathrm{Mg}\left(\mathrm{CO}_{3}\right)_{2}\right]$ is used (Hue and Ikawa, 2006).Acid-tolerant crops can thrive well in the area. While pineapples thrive within a pH range of 4.7-5.7, Irish potatoes require $\mathrm{pH}$ of 4.8 to 5.2 to thrive well (Hue and Ikawa, 2006).

\subsection{Organic Matter}

Organic carbon levels below 2\% (organic matter equivalent of 3.44\%) are taken to be very low for tropical soils (Metson, 1961; Landon, 1991). Based on this rating, all the soil samples analyzed are low in organic matter. This is characteristic of mine soils (Haigh, 1999; Reuter, 2001) and in the case of the study could be the result of the non-adoption of the normal strip-mine policy of storing separately the different strata of the excavated spoil materials. This may have resulted to the acidic and nutrient - deficient materials at the deeper horizons of the soils being brought to the surface. The high temperature and high rainfall of the area which leads to rapid organic matter decomposition and disappearance as well as poor soil management practices (over cultivation, over-grazing, bush-burning etc) are other factors which may be responsible for the low level of organic matter in the area. Mele and Carter (1993) observed that precipitation and temperature affect the formation and distribution of organic carbon.

Fig. 3 shows that except for the cultivated soils, the sub-soils of all soil categories contain more organic matter than the surface soil. Cultivation and fertilization could be responsible for more organic matter for the surface horizons of cultivated soils while erosion and leaching keep surface organic matter levels low for other sites.

According to stocking (1997), when soil organic carbon declines, plant nutrients such as nitrogen and phosphorus are mostly at risk. Adoption of better soil management practices and intensifying the use of organic manures (plant remains, animal droppings and town refuse ash) will go a long way towards bettering the organic matter status of the area thereby making more nutrients available for plant uptake.

\subsection{Particle Size Distribution}

The textural classes of the samples are predominantly sandy clay loam and sandy loam. This implies that the soils are mainly loamy textured and is consistent with findings by Olowolafe (2002) and Anaryu (2005). The soils contain more of sand (a range of $42-84 \%)$ and then clay (6-46\%) with silt as the least (5-29\%). Also, most of the samples have less than 30\% clay content. This reflects the coarse texture and the slow rate of weathering of some mineral contents of granite (Olowolafe, 2002) e.g. quartz and muscovite (Ilaco, 1985). This coarse-textured nature implies that the soils cannot hold much water or nutrients. Water infiltration and water-holding capacity are expected to be poor as a result with surface capping being experienced mainly on the non-vegetated mine dumps. Revegetation and organic amendments will improve the textures of these soils and improve water holding capacity and nutrient availability.

\subsection{Total Nitrogen}

Landon (1991) rated soils with total Nitrogen levels from $0.1-0.2 \%$ as low and $<0.1 \%$ as very low for tropical soils. The mean values of total Nitrogen for the different soil categories as presented on table 4.1 show that while the total nitrogen values (surface and sub-surface) for the undisturbed soil fell within the 'low' range going by the rating by Landon (1991), the values for all other categories fell within the 'very low' range. In other words, the soils of the area are low to very low in their total nitrogen content. Daniels and Zipper (1988) reported that Nitrogen was initially the plant-growth limiting factor on young mine soils in the Appalachian region, but through time, phosphorus became more limiting. Torbert et al (1988) and Reuter (2001) reported that Nitrogen is usually deficient in mine soils and this limits vegetation establishment and sustained productivity. 
The total amount of Nitrogen required to sustain plant growth over time must come from initial fertilization and subsequent symbiotic microbial N-fixation by legumes (Torbert et al, 1988) Organic amendments should be used as a source of mineralizable material to enhance nitrogen levels and extend Nitrogen availability through cycling (Reuter, 2001) since Nitrogen is primarily combined in organic matter in soils (Torbert et al, 1988).

\subsection{Available Phosphorus}

According to Ilaco (1985) and Landon (1991), available phosphorus value below 15ppm is regarded as low for tropical soils. The results of this study show that the surface soils of the cultivated spoils had available phosphorus values that exceeded the critical limit of $15 \mathrm{ppm}$ with the value for the sub-surface soils within the limit. Soils of the other four categories were deficient in available phosphorus. Cultivation and fertilizer application may be responsible for the trend in the cultivated areas.

The tendency of mine soils to fix phosphorus increases over time and because organic bound phosphorus is to subject to $\mathrm{P}$ fixation, it is critical to establish and build an organic - P reservoir in the soil to supply long term plant needs through $\mathrm{P}$ mineralization (Torbert et al, 1988). Low phosphorus levels may hinder nitrogen accumulation since symbiotic N-fixing bacteria have a high phosphorus demand. Therefore, mine soil nitrogen and phosphorus must be managed together, and not as independent factors (Torbert et al, 1988).

\subsection{Exchangeable Bases}

Ilaco (1985) and London (1991) rated soils with <2.0meq/100g as very low in calcium, 2-5meq/100g as low and 5-10 meq $/ 100 \mathrm{~g}$ as medium. The levels of exchangeable calcium show that the soils of the study area are very low to medium in exchangeable calcium.

The soils were found to range from low to medium in exchangeable magnesium based on the ratings by Ilaco (1985) and Landon (1991). According to these authors, exchangeable magnesium values from $1.5-3.0$ meq/100g is medium, 0.5 $1.5 \mathrm{meq} / 100 \mathrm{~g}$ low and $<0.5 \mathrm{meq} / 100 \mathrm{~g}$ very low.

According to Ilaco (1985), levels of exchangeable potassium between $0.1-0.3$ meq/100g soil are regarded as low for tropical and sub-tropical soils and below $0.1 \mathrm{meq} / 100 \mathrm{~g}$ soil very low. Based on this rating, the soils analyzed in this study ranged between low to moderate in their exchangeable potassium content with most of the samples falling within the 'low' and 'very low' ranges. According to Jones and Wild (1975), amounts of exchangeable potassium in the tropical savannah is low. The surface horizons of the cultivated spoils have the highest mean exchangeable potassium value . This could be attributed to cultivation and enrichment of the soils with fertilizers.

Also, Ilaco (1985) and Landon (1991) rated exchangeable sodium levels below $0.1 \mathrm{meq} / 100 \mathrm{~g}$ as very low and $0.1-0.3$ meq $/ 100 \mathrm{~g}$ of soil as low. Based on this, all the soils studied are low in exchangeable sodium. Landon (1991) observed that although sodium could serve as a substitute for potassium, it is not an essential plant nutrient. For this reason, he added that its absence or presence in only small quantities is not usually detrimental to plant nutrition. He observed that when sodium is present in soil in significant quantities, particularly in proportion to other cations present, it can have an adverse effect, not only on many crops, but also on physical conditions of the soil.

The generally low content of exchangeable bases in the spoil soils of the study area could be attributed to the parent material that underlies the area (biotite-granites), the predominance of the low activity clay mineral (kaolinite) in the area, the lateritic nature of the area, the non-adoption of the normal strip-mine policy/the method of placement of excavated materials as well as leaching of essential plant nutrients. Increasing the $\mathrm{pH}$ and organic matter levels will make exchangeable bases more available in the soils.

\subsection{Cation Exchange Capacity}

London (1991) rated soils with CEC value of 5-15 meq/100g as low. Based on this rating, the soils analyzed in this study are low in CEC. The low level of organic matter obtained from this study and the dominance of the low activity clay mineral kaolinite in the study area may have contributed to the low CEC and ECEC values of the soils. The Base saturation percentage values obtained in this study generally ranged from $33.16 \%-90.12 \%$. With a general improvement of $\mathrm{pH}$ and organic matter levels, more basic cations can be made available to satisfy the CEC of the soils as against acidic cations. 


\subsection{Fe, Al and Mn}

Low $\mathrm{pH}$ (below 5.5) makes metals such as $\mathrm{Zn}, \mathrm{Cu}, \mathrm{Mn}, \mathrm{Fe}$ and $\mathrm{Al}$ more soluble for plant uptake (Torbert et al, 1988; Donahua et al, 1990; Reuter, 2001). With the low $\mathrm{pH}$ values obtained in this study, the $\mathrm{Fe}, \mathrm{Al}$, and $\mathrm{Mn}$ values obtained show that the acidic condition of the soils increased the solubility and availability of these metals. This situation encourages leaching of nutrient elements and is best tackled by $\mathrm{pH}$ amelioration.

\section{CONCLUSION}

Whether vegetated or non-vegetated, the tin mine spoil soils of the Jos Plateau are acidic and nutrient-deficient. Although the cultivated spoils generally have higher values for most of the soil parameters, most of these values were below permissible limits.

The findings from this study have shown that cultivation is one way through which the "waste-lands" of the Jos Plateau tin mine fields can be better utilized. The soils need application of land amendment materials such as organic wastes (from plants and animals) and town refuse ash as the soil physico-chemical properties show that all the soils of the area are acidic and deficient in Organic Matter, Total Nitrogen, Available Phosphorus and Exchangeable Bases.

\section{REFERENCES}

[1] Ajaegbu, H.I. (1992): Jos Plateau Environmental Excursion Guide. Jos Plateau Environmental Resources Development Programme, University of Durham, England, UK. 62pp.

[2] Alexander, M.J. (1986): Soil characteristics and the factors influencing their development on mine spoil of the Jos Plateau - Jos Plateau Environmental Resources Development Programme, Interim Report No. 11. University of Durham, Durham, UK.

[3] Alexander, M.J. (1992): Land Use Strategies and their Impact on spoil soils of the Jos Plateau Tin Fields of Nigeria. Jos Plateau Environmental Resources Development Programme, University of Durham, England, U.K. 7pp.

[4] Alexander, M.J. and Kidd, A.D. (2000): Farmers capability and institutional incapacity in reclaiming disturbed Land on the Jos Plateau, Nigeria. Journal of Environmental Management 59:141-155.

[5] Anaryu, J.J. (2005): Nutrient status of mined land soils of Barkin Ladi area of the Jos Plateau, Nigeria. M. Sc. Thesis, Department of Geography and Planning, University of Jos.

[6] Brady, N.C, and Weil, R.R. (1994): The nature and properties of soils (Eleventh Edition). Prentice Hall Inc., New Jersey, USA 740pp.

[7] Bray, R.H. and Kurtz, L.T. (1945): Determination of total, organic and available phosphorus in soils. Soil Science 59:39-45.

[8] Bremner, J.M. (1965): Total Nitrogen. In: C.A. Black et al (ed). Methods of Soil Analysis, Part 2. Agronomy 9: 1149-1178. American Society of Agronomy Inc. Madison Wisconsin.

[9] Daniels, W.L., and Zipper, C.E. (1988): Improving coal surface reclamation in the Central Appalachian region. Pp. 139-162. In: J. Cairns, Jr. (ed) Rehabilitating Damaged Ecosystems. Vol.1. CRC Press, Boca Raton, FL.

[10] Day, P.R. (1965): Particle fractionation and particle size analysis. In: Black, C.A. (ed) Methods of soil analysis, Part 1. Agronomy No. 9 American Society of Agronomy, Madison, Wisconsin, USA.

[11] Donahue, R.L., Miller, R.W. and Shickluna, J.C. (1990): Soils An introduction to soils and plant growth (fifth Edition). New Delhi, Prentice-Hall of India, 667pp.

[12] Gee, G.W. and Bauder, J.W. (1986): Particle size analysis: In: Klute, A. (ed) Methods of soil analysis. Tropical and Mineralogical methods. Madison, Wisconsin. American Society of Agronomy. Pp. 383-411.

[13] Haigh, M.J. (1999): Reclaiming land after surface coal mining. Journal of Balkan Ecology 2(1): 7-14.

[14] Hue, N.V. and Ikawa, H. (2006): Acid soils in Hawaii: Problems and management. Department of Agronomy and Soil Science, College of Tropical Agriculture and Human Resources, University of Hawii, Manoa.

[15] Ilaco, B.V. (1985): Agricultural compendium for rural development in the tropics and sub-tropics. Elsevier Amsterdam. Pp. 738.

[16] Jones, M.J. and Wild, A. (1975): Soils of the West African Savannah. The Cambrian News Ltd., London. Prentice-Hall, New Delhi.

[17] Landon, J.R. (1991): Booker Tropical soil Manual. A handbook for soil survey agricultural land evolution in the tropics and subtropics. Longman Science and Technical. Pp. 474.

[18] Macleod, W.N. Turner, D.C. and Wright, E.P. (1971): The Geology of the Jos Plateau. Geological Survey Bulletin 32.

[19] Mele, P.M. and Carter, M.R. (1993): Effects of climatic factors on the use of Microbial biomass as an indication of changes in soil organic matter, In: Mulongory, K, and Merky, R. (eds) Soil Organic Matter Dynamics and Sustainability of Tropical Agriculture. John Wiley and Sons, New York. Pp. 57-75.

[20] Metson, A.J. (1961): Methods of Soil Analysis for soil Survey Samples. New Zealand Department of Soil and Industrial Research Soil Bureau Bulletin 12, Government Printer, Wellington, New Zealand.

[21] Olowolafe, E.A. (2002): Soil parent materials and soil properties in two separate catchment areas on the Jos Plateau, Nigeria Geojournal 56:201-212.

[22] Reuter, R. (2001): Sewage sludge as an organic amendment for reclaiming surface mine wastes. Soil Science Society of America Journal 65:1736-1744. 
[23] Sengupta, M. (1993): Environmental Imports of mining monitoring, restoration and control. Lewis Publishers, London.

[24] Stocking, M. (1997): Soil erosion and Land degradation. In: O 'Riordan, T. (ed) Environmental Science for environmental Management, Longman, England 224pp.

[25] Tisdale, S.L., and Nelson, W.L. (1975): Soil fertility and fertilizers. Macmillan Publishing Company Inc. New York pp. $189-259$.

[26] Torbert, J.L., Tuladhar, A.R., Burger, J.A., and Bell, J.C. (1988): Minesoil property effects on the height of ten-year-old white pine. Journal of Environmental Quality 17:189-191.

[27] Truog, E. (1948): Lime in relation to availability of plant nutrients. Soil Science 65:1-7.

[28] USDA (1972): Soil Survey Laboratory Methods and Procedures for collecting soil samples. Soil Survey Investigation Report No. 1.

[29] Walkey, A. and Black, C.A. (1934): An Examination of the Method for determining soil organic matter and a proposal for the modification of the chromic acid titration method. Soil Science 37:29-38.

[30] Winbush, S.H. (1963): Afforestation of restored mining land in Nigeria. Common. For. Rev. 42 (113): 255-262.

[31] World Bank (1995): Environmental Assessment of mining project. Environmental Assessment Source Book Update No.22 Environmental Department, World Bank. 